\title{
Time of drone flight of Apis laboriosa Smith in Nepal
}

\author{
BA Underwood \\ Cornell University, Department of Entomology, Ithaca, NY 14853, USA
}

(Received 21 March 1990; accepted 10 July 1990)

\begin{abstract}
Summary - Drones of Apis laboriosa were found to fly in the early afternoon between $12.20 \mathrm{~h}$ and $14.20 \mathrm{~h}$ in Nepal. These flights were not associated with either cleansing flights or orientation flights. Weather conditions during the observation period did not permit flight in the late afternoon or evening. It is suggested that the time of drone flight may serve as an isolating mechanism between the closely related $A$ laboriosa and $A$ dorsata; however, additional data are required.
\end{abstract}

Apis laboriosa / Apis dorsata / drone flight / Nepal

\section{INTRODUCTION}

The taxonomic status of Apis laboriosa Smith 1871 has been the subject of some discussion in recent years. After examining workers of $A$ dorsata and $A$ laboriosa, Sakagami et al (1980) concluded on the basis of morphological characters that they should be considered as separate species. Ruttner (1988) has stated that the differences noted by Sakagami et al, are of a quantitative rather than qualitative nature and do not in themselves justify assigning a specific status to $A$ laboriosa. All the commonly recognized species of Apis (cerana, dorsata, florea, mellifera, and the recentiy "rediscovered" koschevnikovi) exhibit striking differences in drone genitalia.

Although no such differences have been noted in the genitalia of males of $A$ laboriosa and $A$ dorsata, McEvoy and Underwood (1988) argued for recognition of $A$ laboriosa and suggested that a possible isolating mechanism (given the apparent sympatric distribution of the 2 in Assam) could be the time of drone flight. A recent study of $A$ laboriosa in Nepal provided an opportunity for some preliminary observations to be made of the flight activity of Apis laboriosa drones.

\section{MATERIALS AND METHODS}

Studies were carried out at a cliff site at an altitude of $2680 \mathrm{~m}$ in the valley of the Modi Khola river in Kaski District, West-Central Nepal. A viewing platform suspended from bolts anchored to the cliff face made it possible to observe an $A$ laboriosa colony at a distance of less than $1 \mathrm{~m}$. The entire surface of the colony was visible and drones were easily distinguishable from workers. Flight activity of the colony was monitored from 09.30 to $18.30 \mathrm{~h}$ on 4 days during the period 2-10 September 1988. Drone flight was assessed by counting the number of drones arriving on the surface of the colony during 10-min intervals. These counts were begun within about $1 \mathrm{~min}$ after the first drone was seen leaving the colony and ended after drone flight was suspended (ie, no exits or arrivals for a full 
10-min period). On the 14th September, the colony comb was cut and the bees were killed and counted to determine the number of workers and drones in the colony.

\section{RESULTS}

At most times, only worker bees could be seen on the surface of the protective curtain of the A laboriosa colony. On all 4 observation days, drones began to appear on the surface of the curtain between 12.15 and $13.00 \mathrm{~h}$. Flight activity was seen on only 2 days; inclement weather curtailed drone flight at about $13.30 \mathrm{~h}$ on 1 day and entirely prevented it on the other 2 days. In addition, and also apparently because of the weather conditions, no worker flight was observed later than $15.30 \mathrm{~h}$.

Flight by drones was not associated with either cleansing flights (no such flights took place within the observation period) or orientation flights (Lindauer, 1956). Altogether, 357 arrivals of drones were observed, all between 12.20 and $14.20 \mathrm{~h}$. Of 287 arrivals observed on the 10th September, the only day when full flight occurred, $211(74 \%)$ took place between 13.20 and $14.20 \mathrm{~h}$ (fig 1 ; for convenience, observation periods have been combined into 20 min intervals.

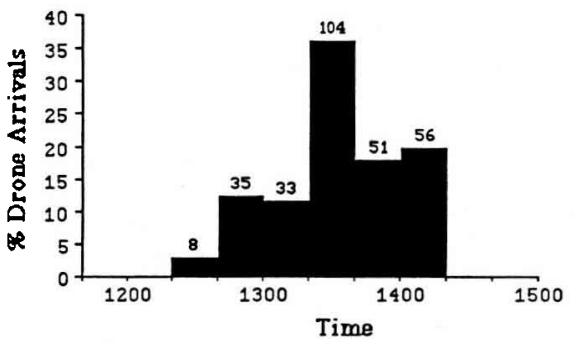

Fig 1. Time of drone flight (arrivals) of Apis laboriosa on the 10th September. Data are broken into 20-min intervals; numbers of drones as indicated.
An orientation flight was observed at $10.30 \mathrm{~h}$ on the 10th September, but no drones were seen taking part in it. From 12.00 to $12.10 \mathrm{~h}$ on that day, 609 workers were observed returning to the nest. Worker flight activity continued unabated at the time the first drone was seen departing at $12.27 \mathrm{~h}$. The activity level was so high that it proved impossible to monitor both worker and drone flight simultaneously. Thus, at the time of initiation of drone flight, there was no diminution in foraging activity, such as might occur prior to an orientation flight (Lindauer, 1956); the flights observed were probably mating flights.

Inspection of the colony on the 14th September revealed that although there were several thousand cells of capped worker brood, there were no eggs or drone brood and only 2 unsealed larvae. Of a total colony population of 21312 only 230 insects were drones.

\section{DISCUSSION}

The absence of eggs and unsealed brood is probably an indication that the colony was making preparations for a migratory move, normal behavior for $A$ laboriosa colonies at this altitude in September (Underwood, 1990). While the migratory status of a colony may influence the timing of orientation flights (Lindauer, 1956), there are no data to suggest that impending migration would affect the time of day at which drones take mating flights.

Preferably, a comparison of the time of drone flight of $A$ laboriosa and $A$ dorsata should be made using data from the 2 species where they occur sympatrically, or at least in relatively close proximity. Unfortunately, data for the time of $A$ dorsata drone flight in Nepal are unavailable (have in fact not been collected). It has been reported that Apis dorsata drones take mating 
flights between $18.15 \mathrm{~h}$ and $19.00 \mathrm{~h}$ in Sabah on the island of Borneo (Koeniger et al, 1988), between 18.00 and $18.45 \mathrm{~h}$ in Sri Lanka (Koeniger and Wijayagunasekera, 1976), and in a 15-20-min period just before dark in Mysore State, India (FC Dyer, personal communication).

Indirect evidence that $A$ dorsata drones in Nepal may follow this pattern of flying at dusk was suggested by observations of worker flight in Rampur, Chitwan District. In March 1984, a time when drones were known to be present (from samples of the populations of the colonies under observation), 2 A dorsata colonies were observed at close range $(<2 \mathrm{~m}$ ) on successive days between 08.30 and 16.30 h. Although workers were foraging actively, no drone flights occurred; indeed, no drones appeared on the curtain surfaces of these colonies (personal observations).

If drones of $A$ dorsata colonies nesting in the Himalayan foothills also fly at dusk, the data for $A$ laboriosa suggest that the time of drone flight may serve as a reproductive isolating mechanism between the two species. Evidence presented here must be regarded as preliminary, however; there is an evident need for additional data. In particular, it must be established that $A$ laboriosa drones do not fly at dusk, even under favorable weather conditions.

\section{ACKNOWLEDGMENTS}

The author thanks His Majesty's Government for permission to travel and conduct research in $\mathrm{Ne}$ pal. Financial support was provided by a grant (No 3682-87) from the National Geographic Society.

Discussions with FC Dyer, RA Morse, and TD Seeley assisted the author in improving upon the original manuscript.

Résumé - Période de vol des mâles d'Apis laboriosa Smith au Népal. Une colonie d'Apis laboriosa qui nichait dans une falaise à $2680 \mathrm{~m}$ d'altitude dans le Centre-Ouest du Népal a été observée à une distance $<1 \mathrm{~m}$. L'activité de vol de la colonie a été suivie pendant $4 j$ en septembre 1988. Les couches externes du rideau protecteur de la colonie étaient habituellement uniquement constituées d'ouvrières mais, lors de chacun des jours d'observation, les mâles ont commencé à faire leur apparition à la surface entre $12 \mathrm{~h}$ 15 et 13 h 00 . Le vol des mâles, observé sur 2 j seulement, se limitait à la période $12 \mathrm{~h} 20-14 \mathrm{~h} 20$. Les conditions météorologiques n'ont pas permis le vol des mâles en fin d'après-midi ni dans la soirée. Les vols des mâles n'étaient associés ni à des vols de propreté, ni à des vols d'orientation. Sur les 287 arrivées observées le 10 septembre, seul jour où les vols se sont pleinement déroulés, 211 (74\%) ont eu lieu entre $13 \mathrm{~h} 20$ et $14 \mathrm{~h} 20$ (fig 1). Les mâles d'Apis dorsata volent le soir (juste avant le coucher du soleil) à Bornéo (Koeniger et al, 1988), au Sri Lanka (Koeniger et Wijayagunasekera, 1976) et dans l'Etat de Mysore en Inde (FC Dyer, communication personnelle). Si c'est aussi le cas pour le Népal, les observations présentées ici suggèrent que la période de vol des mâles peut servir de mécanisme d'isolement entre les espèces $\boldsymbol{A}$ dorsata et $\boldsymbol{A}$ laboriosa étroitement apparentées. Mais il est nécessaire de rassembler des données complémentaires. Apis cerana / Apis laboriosa / vol des
mâles / Nepal

Zusammenfassung - Drohnenflugzeiten von Apis laboriosa Smith in Nepal. Ein Volk von Apis laboriosa, das an einer Felswand im westlichen ZentralNepal in einer Seehöhe von $2680 \mathrm{~m}$ nistete, wurde aus einer Entfernung von weniger als $1 \mathrm{~m}$ beobachtet. Die Flugtätigkeit 
des Volkes wurde vier Tagelang im September 1988 beobachtet. Die äußere Schichte des Schutzvorhanges des Volkes bestand gewöhnlich aus Arbeitsbienen, aber an jedem der vier Tage begannen zwischen 12.15 und 13.00 Drohnen zu erscheinen. Drohnenflug wurde nur zwei Tagelang beobachtet; er war auf die Zeitspanne zwischen 12.20 und 14.20 beschränkt. Die Wetterbedingungen erlaubten keinen Drohnenflug am späten Nachmittag oder Abend. Die Drohnenflüge hatten nichts mit Orientierungs- oder Reinigungsfiügen zu tun. Von 287 beobachteten Ankünften am 10. September, dem einzigen Tag mit vollem Flug, erfolgten 211 (74\%) zwischen 13.20 und 14.20 (Abb 1). Die Drohnen von Apis dorsata fliegen am Abend, unmittelbar vor der Dunkelheit; dies wurde sowohl in Borneo beobachtet (Koeniger et al, 1988), als auch in Sri Lanka (Koeniger und Wijayagunasekera, 1976) und im Staat Mysore, Indien (FC Dyer, persönliche Mitteilung). Wenn diese Flugzeiten auch für Nepal zutreffen, so legen die Beobachtungen der gegenwärtigen Untersuchung nahe, die Drohnenflugzeiten als einen isolierungsmechanismus zwischen den nahe verwandten Arten $A$ dorsata und $A$ laboriosa zu betrachten. Es müssen aber noch weitere Daten gesammelt werden.
Apis cerana / Apis laboriosa / Drohnenflug / Nepal

\section{REFERENCES}

Koeniger N, Koeniger G, Tingek S, Mardan M, Rinderer TE (1988) Reproductive isolation by different time of drone flight between Apis cerana (Fabricius, 1793) and Apis vechti (Maa, 1953). Apidologie 19, 103-106

Koeniger N, Wijayagunasekera HNP (1976) Time of drone flight in the three Asiatic honeybee species (Apis cerana, Apis florea, Apis dorsata). J Apic Res 15, 67-71

Lindauer M (1956) Ueber die Verständigung bei indischen Bienen. Z Vergl Physiol 38, 521557

McEvoy MV, Underwood BA (1988) The drone and species status of the Himalayan honey bee, Apis laboriosa (Hymenoptera: Apidae). $J$ Kans Entomol Soc 61, 246-249

Ruttner F (1988) Biogeography and Taxonomy of Honeybees. Springer Verlag, Berlin

Sakagami SF, Matsumura T, Ito K (1980) Apis laboriosa in Himalaya, the little known world's largest honey bee (Hymenoptera, Apidae). Insecta Matsumurana 19, 47-77

Underwood BA (1990) Seasonal nesting cycle and migration patterns of the Himalayan honey bee, Apis laboriosa. Natl Geogr Res 6, 276-290 